\section{Selective COX-2 Inhibitor (Meloxicam) and Tooth-Supporting Bone Quality. A Histomorphometric Study in Rats}

Bruno César de Vasconcelos Gurgel ${ }^{1}$, Krysna Torres de Almeida ${ }^{2}$, Raniel Fernandes Peixoto ${ }^{3}$, Kenio Costa Lima1, Kamila Rosamilia Kantovitz ${ }^{4}$, Francisco Humberto Nociti-Junior ${ }^{5}$, Sergio de Toledo ${ }^{5}$

\author{
'Department of Dentistry, UFRN - \\ Universidade Federal do Rio Grande \\ do Norte, Natal, RN, Brazil \\ ${ }^{2}$ Private Practice, Delmiro \\ Gouveia, AL, Brazil \\ ${ }^{3}$ Department of Prosthodontics, \\ School of Dentistry of \\ Arcoverde, UPE - Universidade \\ de Pernambuco, PE, Brazil \\ ${ }^{4}$ Department of Pediatric Dentistry, \\ Piracicaba Dental School, UNICAMP \\ - Universidade Estadual de \\ Campinas, Piracicaba, SP, Brazil \\ ${ }^{5}$ Department of Prosthodontics and \\ Periodontics, Piracicaba Dental School, \\ UNICAMP - Universidade Estadual \\ de Campinas, Piracicaba, SP, Brazil
}

Correspondence: Prof. Dr. Bruno César de Vasconcelos Gurgel, Av. Salgado Filho, 1787, Lagoa Nova, 59056-000 Natal, RN, Brasil. Tel: +55-84-32154103. e-mail: bcgurgel@yahoo.com.br
The effects of the non-steroidal anti-inflammatory drugs (NSAIDs) on bone quantity and quality were investigated for years. However, there is lack of information on the impact of NSAIDs on the quality of tooth-supporting alveolar bone in absence of periodontal inflammation. Thus, the aim of this study was to evaluate histometrically the influence of a selective COX-2 NSAID (Meloxicam) on the inter-radicular bone mineral density in rats. Forty-nine adult male Wistar rats were randomly divided into four experimental groups: Subcutaneous injection of $0.9 \%$ sterile saline for 15 days $(\mathrm{G} 1 ; \mathrm{n}=12)$ and 45 days $(\mathrm{G} 2 ; \mathrm{n}=11)$; and subcutaneous injection of Meloxicam for 15 days $(\mathrm{G} 3 ; \mathrm{n}=13)$ and 45 days $(\mathrm{G} 4 ; \mathrm{n}=13)$. Mineral density was histometrically determined in the inter-radicular area of the $1^{\text {st }}$ mandibular molars and data analysis performed by two-way ANOVA ( $\left.\alpha=5 \%\right)$. Results showed no interaction between time and treatment ( $p>0.05)$ and that meloxicam did not affect the alveolar bone density. In contrast, it was found that inter-radicular alveolar bone density increased with time $(91.88 \pm 3.08 \%$ and $92.86 \pm 2.38 \%$ for groups 15 and 45 days, respectively) $(p<0.05)$. Within the limits of this study, daily administration of a selective COX-2 inhibitor (Meloxicam) did not affect the quality of the inter-radicular alveolar bone in absence of periodontal infection.
Key Words: cyclooxygenase-2

inhibitor, meloxicam,

alveolar bone density.

\section{Introduction}

Bone tissue is constantly renewed in a synchronized process mediated by cytokines and growth factors involved in bone resorption and deposition. The understanding of the mechanisms involved with bone homeostasis is crucial, especially to approach metabolic bone disorders leading to bone loss and consequently decreased quality of life (1).

The effects of inflammatory mediators (such as prostaglandins) and growth factors on osteoclasts and osteoblasts may trigger the start of bone adaptive changes in response to mechanical (2) or endocrine signals $(2,3)$. Prostaglandins are produced from membrane phospholipids by sequential actions of phospholipase A2 (PLA2) and cyclooxygenase (COX) (4).

Two COX isoforms have been identified in human tissues: the regulatory COX-1 enzyme (which provides homeostatic levels of prostaglandins) and the inducible COX-2 (which can be stimulated by inflammation) (4). COX inhibitors are known as non-steroidal anti-inflammatory drugs (NSAIDs) and for years the effects of these drugs on bone quantity and quality have been investigated. Previous studies utilizing specific COX-2 inhibitors demonstrate that blocking of COX-2 activity may prevent bone resorption $(1,4,5-7)$, but it may also delay healing in bone fractures $(8,9)$ and during alveolar bone repair in rats $(10)$.
NSAIDs are drugs able to block the potential costimulation of osteophytogenesis by mediators of inflammation (11) and prescribed primarily for chronic management of rheumatic conditions. In dentistry, NSAIDs are often used to control pain and inflammation after several procedures such as tooth extraction, orthodontic movement, orthognathic procedures and other oral surgeries (10). Among these NSAIDs, Meloxicam is prescribed worldwide, due to its analgesic and anti-inflammatory actions. Meloxicam, 4-hydroxy-2-methyl-N-(5-methyl-2tiazolil)-2H-1,2-benzotiacina-3-carboxamide-1,1-dioxide, is a highly specific COX-2 inhibitor and offers high efficiency with very few side effects on the gastrointestinal and renal systems $(6,12)$.

Previous animal studies showed that Meloxicam may prevent bone loss in experimental periodontitis $(6,7,10,13)$, possibly by controlling COX-2 enzyme function, which is up-regulated in highly-inflamed periodontal tissues (12).

Nowadays, it is proposed that alveolar bone quality is a critical factor for teeth and dental implant general health and long-term stability. Thus, animal models are successfully used to assess the impact of systemic conditions and hormone replacement therapy on alveolar bone quality (14). Because of the lack of information on the impact of 
NSAIDs on the quality of tooth-supporting alveolar bone in absence of periodontal inflammation, the aim of the present study was to assess the effect of daily NSAIDs administration to the inter-radicular alveolar bone in rats by histological analysis.

\section{Material and Methods}

\section{Animals}

Forty-nine male Wistar rats (Rattus norvegicus albinus), weighing 250-350 $\mathrm{g}$ and aged 90 days at the beginning of the experiment were used. During the experiment, the animals were maintained in plastic cages (4-5 per cage) under the same environmental conditions, with solid food and water ad libitum throughout the study. The protocol was approved by the University of Campinas Institutional Animal Care and Use Committee (protocol number 265-2).

\section{Experimental Design}

At the study start, the animals were randomly assigned to one of the following experimental groups:

Group 1: Daily (1x/day) Subcutaneous injection (SC) of sterile saline $(1 \mathrm{~mL} / \mathrm{kg})$ for 15 days $(\mathrm{n}=12)$; Group 2: Daily (1x/day) SC injection of sterile saline $(1 \mathrm{~mL} / \mathrm{kg})$ for 45 days $\Xi \quad(n=11) ;$ Group 3: Daily (1x/day) SC injection of Meloxicam (Movatec ${ }^{\oplus}$, Boehringer Ingelheim do Brasil Química e Farmacêutica Ltda., Itapecerica da Serra, SP, Brazil) (3 $\mathrm{mg} / \mathrm{kg}$ ) (7) for 15 days ( $\mathrm{n}=13)$; Group 4: Daily (1x/day) SC injection of Meloxicam (3 mg/kg) (7) for 45 days ( $n=13)$.

\section{Histological Analysis}

The animals were euthanized by deep anesthesia after the experimental period. The jaws were removed and divided at the mandibular symphysis in hemi-mandibles,

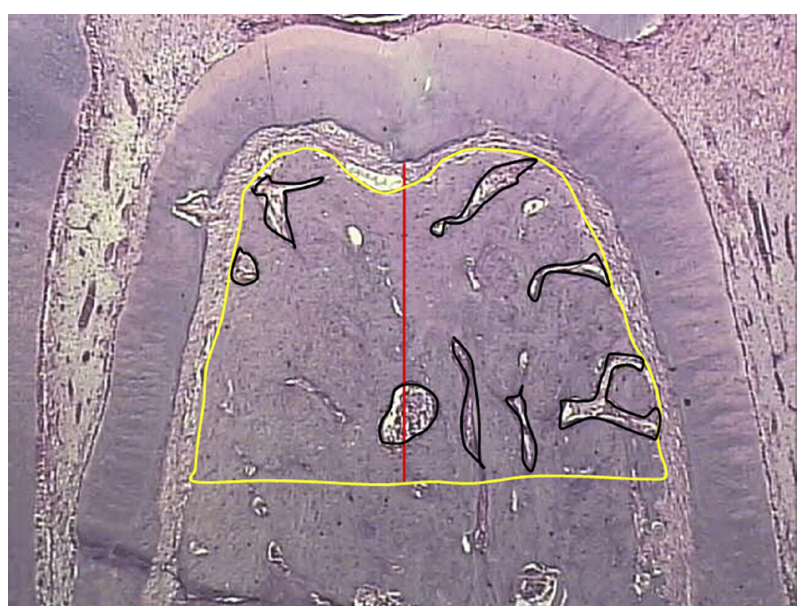

Figure 1. Photomicrograph showing the inter-radicular region of the first mandibular molar where bone density was histometrically determined (yellow line). Mineralized regions circumscribed in black (original magnification: $6.25 \times$ ). before fixing in 4\% neutral formalin ( $\mathrm{pH} 7.2$ - 7.4) for 48 h. Demineralization was performed in a 1:1 solution of $50 \%$ formic acid and 20\% sodium citrate (Morse solution) for 60 days. Next, the demineralized bone was dehydrated in absolute alcohol, diaphanized in xylol and embedded in paraffin. Longitudinal serial sections $(6 \mu \mathrm{m})$ were obtained in a mesial-distal direction, and stained with hematoxylin and eosin.

After excluding the first and the last sections in which the furcation region was evident, ten equally distant sections of each tooth were selected for histomorphometric analysis (Fig. 1). Using an image-analysis system (UTHSCSA ImageTool 3.0, San Antonio, TX, USA), the percentage of mineralized bone (alveolar bone density) in the inter-radicular area of the 1st mandibular molar was histometrically determined by a blinded and calibrated examiner.

\section{Statistical Analysis}

Mean values of alveolar bone density were determined for each group and the Kolmogorov-Smirnov test was used to determine data normality. Next, two-way ANOVA test was used to detect differences between groups according to time and treatment. All analyses were performed using a $5 \%$ significance level $(\alpha=0.05)$.

\section{Results}

Quantitative data of alveolar bone density determined by histomorphometric analyses are in Table 1 and Figure 2. There were no statistically significant differences between time and treatment ( $p=0.305)$, assuming that the effect of saline and Meloxicam was the same on the quality of the inter-radicular alveolar bone at 15 and 45 days. Interestingly, data analysis showed that interradicular bone density increased with time regardless of the treatment group $(88.81 \pm 3.21 \% / 91.88 \pm 3.08 \%$ and $87.78 \pm 4.49 \% / 92.86 \pm 2.38 \%$ for saline and meloxicam administration at $15 / 45$ days, respectively) $(p<0.001)$.

Table 1. Mean and standard deviation (SD) of the percentage of alveolar bone density for the control and test groups

\begin{tabular}{lcccc}
\hline \multirow{2}{*}{ Period (days) } & Saline & Meloxicam & \multirow{2}{*}{ F } & $\mathrm{p}^{*}$ \\
& Mean (SD) & Mean (SD) & & \\
\hline \multirow{2}{*}{15 days } & $88.81 \%$ & $87.78 \%$ & & \\
& $(3.21)$ & $(4.49)$ & & \\
45 days & $91.88 \%$ & $92.86 \%$ & & \\
Time & $(3.08)$ & $(2.38)$ & & \\
Treatment & & & 17.582 & $\mathrm{p}<0.001$ \\
Time-Treatment & & & 0.000 & $\mathrm{p}=0.983$ \\
\hline
\end{tabular}

* Two-way ANOVA. 
Figure 3 illustrates the histological aspects of bone density observed after administration of sterile saline for

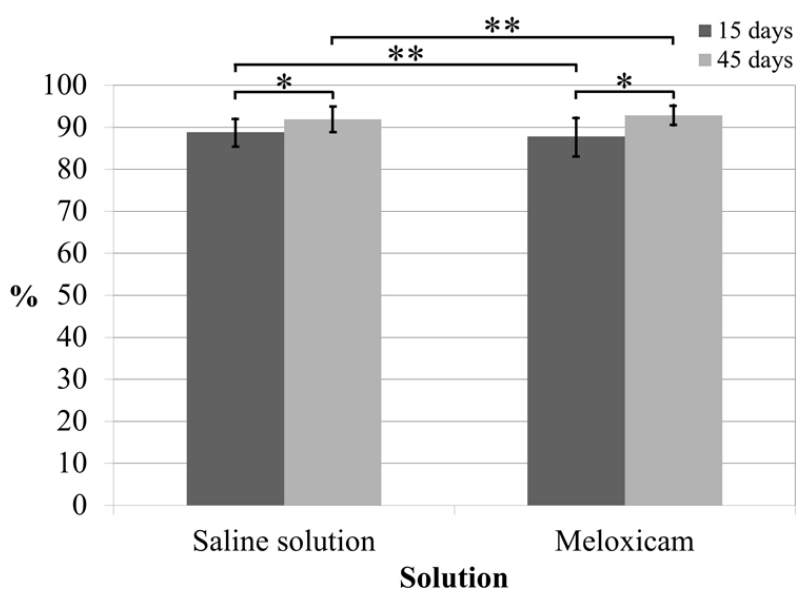

Figure 2. Percentage of alveolar bone density after subcutaneous injections of sterile saline solution (15 days [G1] and 45 days [G2]) and meloxicam ( 15 days [G3] and 45 days [G4]). One asterisk indicate statistically significant difference $(\mathrm{p}<0.05)$ and two asterisks indicate no statistically significant difference ( $p>0.05)$.
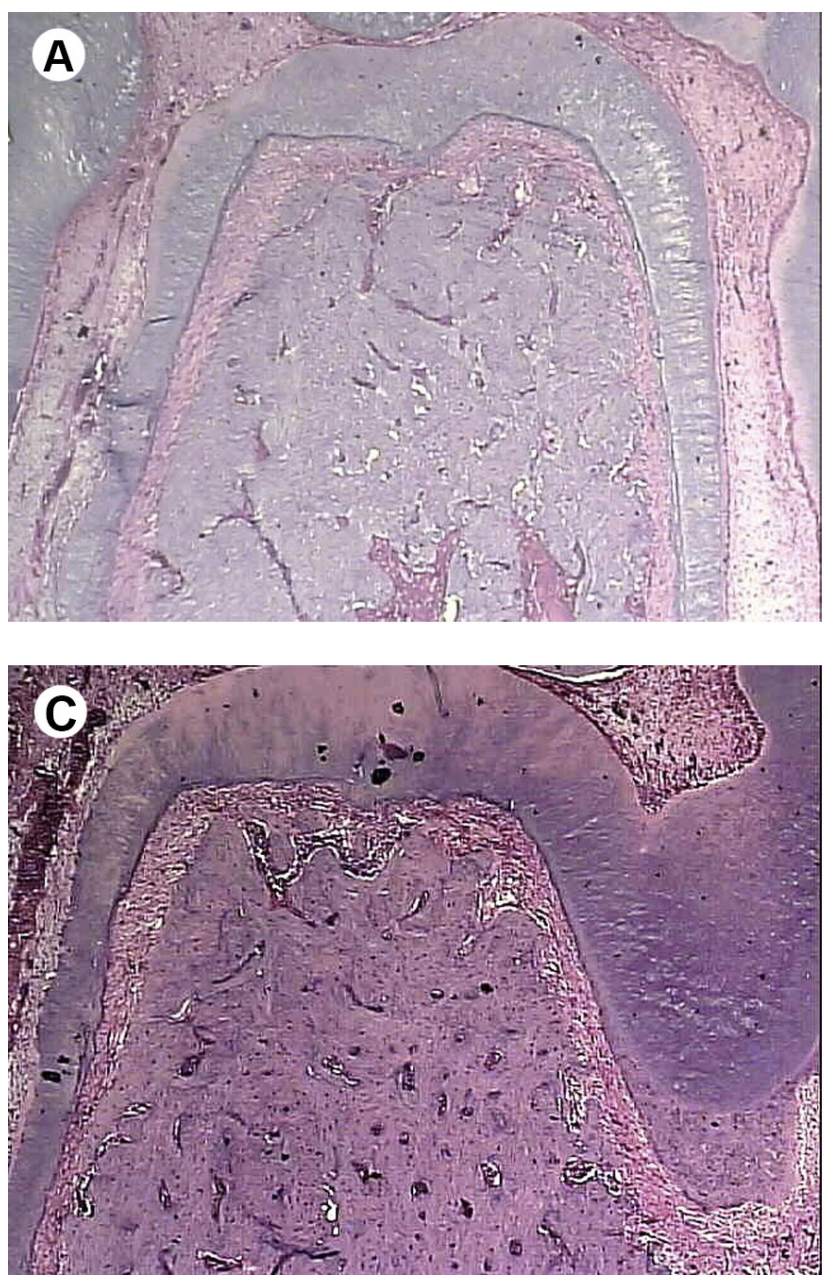

15 days (A) and 45 days (B) and Meloxicam for 15 days (C) and 45 days (D).

\section{Discussion}

The present study demonstrated that meloxicam, a selective COX-2 inhibitor, did not affect alveolar bone density in the inter-radicular area of periodontally healthy mandibular $1^{\text {st }}$ molars in rats. We additionally found that, regardless of treatment, bone density increased with time. Therefore, these findings suggest that, in physiological conditions, NSAIDs did not impact the quality of the toothsupporting alveolar bone.

Morton et al. (15) reported that certain NSAID classes may have different effect on bone metabolism. Selective COX-2 inhibitors may have greater effects on bone metabolism, as compared with COX-1 inhibitors, since production of prostaglandins in osteoclasts is primarily mediated by COX-2 (16). Thus, selective COX-2 inhibitors have been suggested to reduce bone remodeling and resorption, conserving trabecular bone mass and
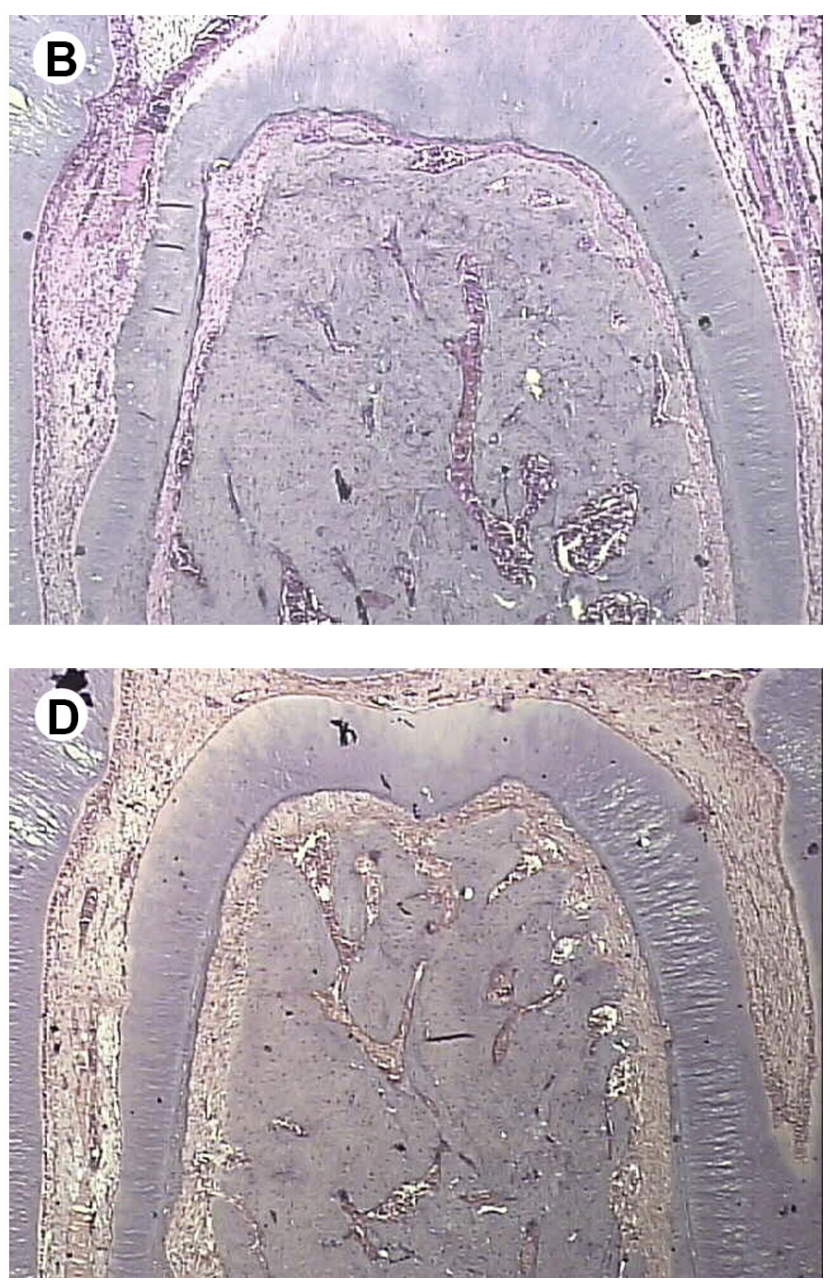

Figure 3. Photomicrograph showing bone density after subcutaneous injections of sterile saline for 15 days (A) and 45 days (B) and meloxicam for 15 days (C) and 45 days (D). 
architecture (4). Studies with bone marrow cultures from COX-2 knockout mice demonstrated a marked decrease in osteoclast responses to stimulators of bone resorption and that selective COX-2 inhibitors blocked osteoclast formation in this system (3).

The impact of meloxicam administration on the alveolar bone loss resulting from experimental periodontitis has been previously investigated $(6,7)$ and the results suggested that meloxicam may significantly decrease periodontitisresulting bone loss; these findings are in line with others $(1,4,5,13)$. Fewer renal side effects have been reported for meloxicam compared to other NSAIDs $(6,12)$, indicating that meloxicam treatment may be used for a longer time (17). Interestingly, aspirin was reported to potentiate the effect of selective COX-2 inhibitors, acting on prostaglandin production (dependent on arachidonic acid), as well as on nitric oxide (NO) and nuclear factor kappa-light-chainenhancer of activated B (NF-kB) production (independent from arachidonic acid) in cells, leading to increased bone density at multiple skeletal sites in men and women (5).

On the other hand, Shen et al. (18) observed that short-term administration of selective COX-2 inhibitors resulted in suppression of bone formation and increased $\Xi$ bone resorption in rats. COX-2 function was reported as essential for fracture healing, since this enzyme is critically involved in bone repair and required for intramembrane and endochondral bone formation (8). After continuous administration, selective COX-2 inhibitors (meloxicam) may negatively influence bone healing in cortical and cancellous bone around titanium implants inserted in rats (19). In the present study, in both groups, saline and meloxicam, there was an increase in alveolar bone density with time, indicating that meloxicam alone did not affect tooth-supporting bone quality.

The role of vascular endothelial growth factor (VEGF) in bone density was investigated during the bone repair. VEGF, described as the most important molecule for regulating angiogenesis, plays a critical role in bone homeostasis (20). VEGF receptor activation induces endothelial cell mobilization, recruitment, differentiation and proliferation, as well as the enrollment and survival of mesenchymal progenitor cells, osteoblasts and osteoclasts $(21,22)$. Although systemic therapies with selective COX2 inhibitors may affect VEGF expression in rats (13), the results of this study showed similar bone repair between saline and Meloxicam after 45 days and this finding suggests no direct relationship between Meloxicam and increased VEGF expression. Thus, the increased bone density observed in 45 days compared to 15 days may suggest other mechanisms, including those not depending on arachidonic acid. However, Arantes et al. (10) reported an alveolar bone repair delay following daily administration of meloxicam for 7 days after tooth extraction in rats. Taken together, these findings suggest that meloxicam may affect bone homeostasis in a VEGF-dependent manner, at least in part.

Irrational use of NSAIDs, selective and nonselective, is associated with a range of potential adverse effects, including gastric mucosa damages and an increased risk of adverse cardiovascular effects. The risk of different events depends on the clinical context, medication and dose (23). In addition, long-term NSAIDs administration is employed for the treatment of specific diseases including, for example, the rheumatoid arthritis. In these cases, a secondary osteoporosis with bone loss in the joints is easily recognized and may increase the risk of fractures and accompanying co-morbidities in these subjects (24). Specifically in relation to Meloxicam, Bezerra et al. (6) examined the effect of this drug on gastric mucosa of rats and found that the dosage of up to $3 \mathrm{mg} / \mathrm{kg}$ did not produce significant gastric effects. Nevertheless, new therapeutic alternatives to the treatment of diseases involving bone metabolism like osteoporosis has been carried out for years and the phytotherapeutic agents showed promising results (25).

Further controlled clinical studies are required to evaluate their long-term benefits and to search for less harmful alternative therapies (9). In addition, other analyses including immunohistochemical and molecular biology and other drugs, may be performed to clarify the effect of NSAIDs on cell and tissue behavior during the process of bone repair, because multiple mechanisms (not yet fully elucidated) may be related to inflammation and bone resorption and deposition processes, such as VEGF expression, receptor activator of nuclear fator $k B$, RANK/RANKL/receptor osteoprotegerin (OPG) and tumor necrosis factor (TNF). Thus, knowledge of the behavior and mechanisms of selective COX-2 inhibitors is required for future clinical applications.

Within the limits of the present study, it was concluded that daily administration of a selective COX-2 inhibitor (Meloxicam) did not affect the quality of the inter-radicular alveolar bone in absence of periodontal infection. However, further pre-clinical and clinical studies should be considered in order to determine the relevance of long-term NSAIDs administration to the tooth-supporting alveolar bone quality and the potential involved mechanisms.

\section{Resumo}

Os efeitos dos fármacos anti-inflamatórios não esteroidais (AINEs) sobre a quantidade e qualidade óssea tem sido investigados ao longo dos anos.Entretanto, há falta de informação sobre o impacto dos AINEs na qualidade do osso alveolar de suporte na ausência de inflamação periodontal. Assim, o objetivo deste estudo foi avaliar, histometricamente, a influência de um AINE seletivo para COX-2 (Meloxicam) na densidade mineral óssea inter-radicular em ratos. Quarenta e nove ratos Wistar, machos e adultos foram divididos aleatoriamente em quatro grupos experimentais: injeções subcutâneas de 0,9\% de solução salina estéril 
por 15 dias $(\mathrm{G} 1, \mathrm{n}=12)$ e 45 dias $(\mathrm{G} 2, \mathrm{n}=11)$; e injeções subcutâneas de Meloxicam por $15(\mathrm{G} 3, \mathrm{n}=13)$ e 45 dias $(\mathrm{G} 4, \mathrm{n}=13)$. A densidade mineral foi determinada histometricamente na área inter-radicular dos primeiros molares mandibulares e a análise dos dados realizada por meio de ANOVA $(\alpha=5 \%)$. Os resultados mostraram nenhuma interação entre tempo e tratamento $(p>0,05)$ e que o meloxicam não afetou a densidade óssea alveolar. Em contraste, foi encontrado que a densidade óssea alveolar inter-radicular aumentou ao longo do tempo $(91,88 \pm 3,08 \%$ e $92,86 \pm 2,38 \%$ para os grupos 15 e 45 dias, respectivamente) $(p<0,05)$. Dentro dos limites deste estudo, a administração diária de um inibidor seletivo para COX-2 (Meloxicam) não afetou a qualidade do osso alveolar inter-radicular na ausência de infecção periodontal.

\section{References}

1. Kasukawa Y, Miyakoshi N, Srivastava AK, Nozaka K, Maekawa S, Baylink DJ, et al.. The selective cyclooxygenase-2 inhibitor celecoxib reduces bone resorption, but not bone formation, in ovariectomized mice in vivo. Tohoku J Exp Med 2007;211:275-283.

2. Richards JB, Joseph $L$, Schwartzman $K$, Kreiger N, Tenenhouse A,

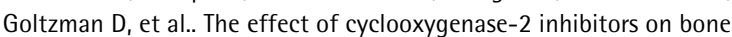
mineral density: Results from the Canadian Multicentre Osteoporosis Study. Osteoporos Int 2006;17:1410-1419.

3. Okada Y, Lorenzo JA, Freeman AM, Tomita M, Morham SG, Raisz LG, et al.. Prostaglandin $\mathrm{G} / \mathrm{H}$ synthase-2 is required for maximal formation of osteoclast-like cells in culture. J Clin Invest 2000;105:823-832.

4. Gregory LS, Kelly WL, Reid RC, Fairlie DP, Forwood MR. Inhibitors of cyclo-oxygenase-2 and secretory phospholipase A2 preserve bone architecture following ovariectomy in adult rats. Bone 2006;39:134142.

5. Carbone LD, Tylavsky FA, Cauley JA, Harris TB, Lang TF, Bauer DC, et al.. Association between bone mineral density and the use of nonsteroidal anti-inflammatory drugs and aspirin: impact of cyclooxygenase selectivity. J Bone Miner Res 2003;18:1795-1802.

6. Bezerra MM, de Lima V, Alencar VB, Vieira IB, Brito GA, Ribeiro RA, et al.. Selective cyclooxygenase-2 inhibition prevents alveolar bone loss in experimental periodontitis in rats. J Periodontol 2000;71:1009-1014.

7. Gurgel BC, Duarte PM, Nociti FH, Jr., Sallum EA, Casati MZ, Sallum AW, et al.. Impact of an anti-inflammatory therapy and its withdrawal on the progression of experimental periodontitis in rats. J Periodontol 2004;75:1613-1618.

8. Simon AM, Manigrasso MB, O'Connor JP. Cyclo-oxygenase 2 function is essential for bone fracture healing. J Bone Miner Res 2002;17:963-976.

9. Geusens P, Emans PJ, de Jong JJ, van den Bergh J. NSAIDs and fracture healing. Curr Opin Rheumatol 2013;25:524-531.

10. Arantes RV, Cestari TM, Viscelli BA, Dionisio TJ, Garlet GP, Santos $\mathrm{CF}$, et al.. Meloxicam temporally inhibits the expression of vascular endothelial growth factor receptor (VEGFR)-1 and VEGFR-2 during alveolar bone repair in rats. J Periodontol 2015;86:162-172.

11. Jones MD, Tran CW, Li G, Maksymowych WP, Zernicke RF, Doschak MR. In vivo microfocal computed tomography and micro-magnetic resonance imaging evaluation of antiresorptive and antiinflammatory drugs as preventive treatments of osteoarthritis in the rat. Arthritis Rheum 2010;62:2726-2735.

12. Morton RS, Dongari-Bagtzoglou Al. Cyclooxygenase-2 is upregulated in inflamed gingival tissues. J Periodontol 2001;72:461-469.

13. Oliveira TM, Sakai VT, Machado MA, Dionisio TJ, Cestari TM, Taga R, et al.. COX-2 inhibition decreases VEGF expression and alveolar bone loss during the progression of experimental periodontitis in rats. J Periodontol 2008;79:1062-1069.

14. Cesar-Neto JB, Benatti BB, Sallum EA, Casati MZ, Nociti FH, Jr. The influence of cigarette smoke inhalation and its cessation on the toothsupporting alveolar bone: a histometric study in rats. J Periodontal Res 2006;41:118-123.

15. Morton DJ, Barrett-Connor EL, Schneider DL. Nonsteroidal antiinflammatory drugs and bone mineral density in older women: the Rancho Bernardo study. J Bone Miner Res 1998;13:1924-1931.

16. Cryer B, Feldman M. Cyclooxygenase-1 and cyclooxygenase-2 selectivity of widely used nonsteroidal anti-inflammatory drugs. Am J Med 1998;104:413-421.

17. Feldman M, McMahon AT. Do cyclooxygenase-2 inhibitors provide benefits similar to those of traditional nonsteroidal anti-inflammatory drugs, with less gastrointestinal toxicity? Ann Intern Med 2000;132:134-143.

18. Shen $\mathrm{CL}$, Yeh JK, Wang X. Short-term supplementation of COX-2 inhibitor suppresses bone turnover in gonad-intact middle-aged male rats. J Bone Miner Metab 2006;24:461-466.

19. Ribeiro FV, Nociti FH, Jr., Sallum EA, Casati MZ. Effect of aluminum oxide-blasted implant surface on the bone healing around implants in rats submitted to continuous administration of selective cyclooxygenase-2 inhibitors. Int J Oral Maxillofac Implants 2009;24:226-233.

20. Lee JH, Um S, Jang JH, Seo BM. Effects of VEGF and FGF-2 on proliferation and differentiation of human periodontal ligament stem cells. Cell Tissue Res 2012;348:475-484.

21. Chim SM, Tickner J, Chow ST, Kuek V, Guo B, Zhang G, et al.. Angiogenic factors in bone local environment. Cytokine Growth Factor Rev 2013;24:297-310.

22. Maes C. Role and regulation of vascularization processes in endochondral bones. Calcif Tissue Int 2013;92:307-323.

23. Trelle $S$, Reichenbach $S$, Wandel $S$, Hildebrand $P$, Tschannen $B$, Villiger PM, et al.. Cardiovascular safety of non-steroidal anti-inflammatory drugs: network meta-analysis. BMJ 2011; 342:c7086.

24. Krieckaert $C L$, Nurmohamed MT, Wolbink G, Lems WF. Changes in bone mineral density during long-term treatment with adalimumab in patients with rheumatoid arthritis: a cohort study. Rheumatology (Oxford) 2013;52:547-553.

25. Dang ZC, Lowik C. Dose-dependent effects of phytoestrogens on bone. Trends Endocrinol Metab 2005;16:207-213. 